UDC 557.15

\title{
INFLUENCE OF LONG-TERM PER ORAL TAURINE TREATMENT ON ACTIVITY OF LIVER ENZYMES IN MATURE RATS
}

\author{
R. D. Ostapiv ${ }^{1,2}$, Chr. S. Ostapivi, V. V. Manko ${ }^{1}$ \\ ${ }^{1}$ Ivan Franko National University of Lviv, 4, Hrushevskyi St., Lviv 79005, Ukraine \\ ${ }^{2} \mathrm{SSRCl}$ of Veterinary Medicinal Products and Feed Additives \\ 11, Donetska St., Lviv 79019, Ukraine \\ e-mail: romostapiv@gmail.com
}

Taurine is sulfur-containing derivative of methionin and cysteine that plays a key role in glucose and lipid metabolism. Taurine regulates antioxidant defense system, membrane potential of mitochondria, and glycolysis. Thus, it might have a serious impact on cell metabolism in mammals. The aim of this work was to study the influence of long-term per oral taurine treatment $(5,10$ and $20 \mathrm{mg} / \mathrm{kg})$ on the antioxidant defense system, cholesterol content, activity of transaminases and lactate dehydrogenase in rat liver. To achieve that goal, mature Wistar rats (weight 140-160 g, age - 4 months) were divided in four groups - control, rats which once a day during 28 days were injected drinking water in esophagus, and three experimental groups, that were injected taurine solution in concentrations: I - $5 \mathrm{mg} / \mathrm{kg}$, II $-10 \mathrm{mg} / \mathrm{kg}$ and III $-20 \mathrm{mg} / \mathrm{kg}$ of body mass. After 28 days, rats were decapitated under light chloroform narcosis and liver mass was determined. In liver, content of cholesterol, TBA-active products and activity of antioxidant defense enzymes, transaminases, and lactate dehydrogenase were measured.

Our results show that after a long-term per oral taurine treatment liver mass decreased by $27.5 \%$ comparing to control group. Lactate dehydrogenase activity increased two times, while the activity of alanine aminotranferase and aspartate aminotransferase in mitochondrial fraction increased by $40-90 \%$ in liver of animals of all experimental groups. Total activity of these enzymes in rat liver increased by $20-37 \%$ in all experimental groups. Cholesterol content increased dy $32.4 \%$ in rats of experimental group II. This may indicate intensification of liver metabolism. The content of TBA-active products in submitochondrial and mitochondrial fractions increased more than two times in rats of experimental groups II and III. The activity of superoxide dismutase in the submitochondrial fraction increased by 49.8 and $36.5 \%$ in liver of that rats. The activation of superoxide dismutase and a rise in content of TBA-active products may suggest a rise of free oxygen radicals production and inability of antioxidant defense system. These results may indicate a negative influence of taurine in doses higher than $5 \mathrm{mg} / \mathrm{kg}$, since the balance between antioxidant protection and lipid peroxidation processes was violated.

Keywords: rats, liver, antioxidant defense, taurine, lactate dehydrogenase, transaminases

() 2018 R. D. Ostapiv et al.; Published by the Ivan Franko National University of Lviv on behalf of Біологічні Студії / Studia Biologica. This is an Open Access article distributed under the terms of the Creative Commons Attribution License (http://www.budapestopenaccessinitiative.org/ and Creative Commons Attribution 4.0 License), which permits unrestricted reuse, distribution, and reproduction in any medium, provided the original work is properly cited.

ISSN 1996-4536 (print) • ISSN 2311-0783 (on-line) • Біологічні Студії / Studia Biologica • 2018 • Том 12/№1 • С. 25-34 


\section{INTRODUCTION}

Liver is a key organ in mammals, that can influence an intensity of energy metabolism of the whole organism [19]. Hepatocytes are main cell type in liver and it is a central link in biochemical transformations in the energetic metabolism [27]. Taurine that is a derivative of sulfur-containing aminoacids methionine and cysteine participates in regulation of liver metabolic activity [26].

Taurine is a component of bile acids that facilitates cholestasis, maintains activity of antioxidant defense system and electron transport chain [12]. Depletion of taurine results in a decrease of mitochondria quantity in hepatocytes, increase of peroxidative stress, and cell membrane damage, hepatocyte apoptosis, and liver fibrosis [4]. Surplus of taurine has a variable effect on liver metabolism. Per oral treatment of rats diabetic with taurine in doses $50-100 \mathrm{mg} / \mathrm{kg}$ results in activation of antioxidant defense system and a decrease in TBA-active products [12]. Treatment of rats with $1 \%$ taurine solution for 15 days increased the content of TBA-active products and catalase activity in liver [16]. Per oral treatment for 28 days with taurine in doses 40 and $100 \mathrm{mg} / \mathrm{kg}$ increased lactate dehydrogenase activity and intensified mitochondrial respiration of hepatocytes $[22,23]$. However, lipid peroxidation processes were also increased that resulted in the increase of TBA content [24]. Increase of AST activity in blood plasm points on hepatocyte membrane damage that may be caused by uncontrolled elevation of peroxidation processes [21].

Thus, it is necessary to indentify optimal doses of taurine that influence liver metabolism without negative consequences. This will enable development new pharmacological preparations and feed additives containing taurine. The aim of our work was to study influence of long-term per oral taurine treatment on the activity of liver enzymes of in mature rats.

\section{MATERIALS AND METHODS}

Experiments were carried out using male Wistar rats. The rats were 4 months old with body mass $140-160 \mathrm{~g}$ at the beginning of the experiment. All manipulations with animals were carried out according to the European Convention "For the protection of vertebrate animals used for experimental and other scientific purposes" and Ukrainian Law "On protecting animals of ill-treatment". Approval for study was obtained from the Ethics Committe of the Biological faculty of Ivan Franko National University of Lviv (Ethical Committee Approval, protocol No 8-03 by March 03, 2018). Animals were randomly divided into four groups: one control group $(n=4)$ and the experimental groups. During 28 day period, animals were daily injected in esophagus: control group - drinking water, group I, II and III-solution of taurine (5, 10 and $20 \mathrm{mg} / \mathrm{kg}$ of body weight, respectively) $(n=4)$. On $29^{\text {th }}$ day, the animals were decapitated under light chloroform anesthesia. Liver was extirpated, weighted and homogenized in solution of such composition: sucrose - 250 mM, EGTA - 1 mM, HEPES - 10 мM; pH 7.2 [9]. The homogenate was centrifuged for $15 \mathrm{~min}$ at $1,000 \mathrm{~g}$. After that, supernatant was discarded and centrifuged for $20 \mathrm{~min}$ at $9,000 \mathrm{~g}$. After second centrifugation supernatant was discarded and precipitate was resuspended in homogenating solution. In supernatant and resuspended precipitate, the activities of transaminases (aspartate (AST) and alanine (ALT) transaminase $\lambda_{\text {abs }}=412 \mathrm{~nm}$ ) were determined according to Reitman and Frankel [6].

ISSN 1996-4536 (print) • ISSN 2311-0783 (on-line) • Біологічні Студії / Studia Biologica • 2018 • Том 12/№1 • С. 25-34 
Activity of such antioxidant defense enzymes in mitochondrial and submitochondrial fraction were measured: superoxide dismutase with nitroblue tetrazolium (SOD; $\lambda_{\text {abs }}=540 \mathrm{~nm}$; UI/mg of protein [1]), glutathione peroxidase - with Elman reagent (GPO; $\lambda_{\text {abs }}=412 \mathrm{~nm} ; \mu \mathrm{mol} \mathrm{GSH} / \mathrm{min} \times \mathrm{mg}$ of protein [17]); catalase - with ammonium molibdate and hydrogen peroxide (CAT; $\lambda_{\text {abs }}=410 \mathrm{~nm} ; \mu \mathrm{mol} \mathrm{H}_{2} \mathrm{O}_{2} / \mathrm{min} \times \mathrm{mg}$ of protein [11]). The content of TBA-active products was determined using phosphorwolframic and thiobarbituric acids ( $\mu \mathrm{mol} / \mathrm{mg}$ of protein [10]). Protein content was measured using Lowry method [14]. In supernatant, the activity of lactate dehydrogenase was defined by kinetic method ( $\mathrm{LDH}$; UI/mg of protein; $\lambda_{\text {abs }}=340 \mathrm{~nm}$ [5]). In the submitochondrial fraction, cholesterol content was measured by the enzymatic method $\left(\lambda_{\text {abs }}=500 \mathrm{~nm} ; \mu \mathrm{mol} / \mathrm{mg}\right.$ of protein [6]).

The inter relations between superoxide dismutase and catalase (SOD/CAT), glutathione peroxidase and catalase activity (GPO/CAT) and superoxide dismutase and glutathione peroxidase activities (SOD/ GPO) were calculated. Ratio between the activity of antioxidant defense enzymes and content of TBA-active products was calculated (index of antioxidant status):

$$
\mathrm{AOD} / \mathrm{TBA}=\frac{\mathrm{SOD} \times \mathrm{CAT} \times \mathrm{GPO}}{\mathrm{TBA}},
$$

where SOD; CAT and GPO are activities of corresponding enzymes of antioxidant defense, TBA - content of TBA-active products.

The results were analyzed by variation statistics using Microsoft Excel 2010. Results were presented in the form of arithmetic mean and arithmetic mean error $(M \pm m)$, significance of the data difference was calculated using the paired samples Student $t$-test for independent samples [15].

\section{RESULTS AND DISCUSSION}

The liver mass in animals of the control group was $8.04 \pm 0.48 \mathrm{~g}$. In rats of I and III experimental groups, the liver mass did not differ significantly from the control values $(7.71 \pm 0.46$ and $8.37 \pm 0.61 \mathrm{~g}, \mathrm{n}=4)$. The mass of liver in animals of II experimental group was $6.30 \pm 0.34 \mathrm{~g}$ that lower by $27.5 \%(P<0.05, \mathrm{n}=4)$ than in control.

Literature data showed that a prolonged oral administration of taurine in doses of 40 and $100 \mathrm{mg} / \mathrm{kg}$ leads to an increase in the LDH activity in rat liver [23]. It was found that at lower doses of taurine $(5-20 \mathrm{mg} / \mathrm{kg})$, the activity of this enzyme increased by 1.65-2 times compared to control (Table 1).

Cholesterol content in liver of I and III experimental groups did not differ from the control indicators, and in the II experimental group it was $32.4 \%$ higher than in the control group. It was found that taurine increased bile acid content in liver [13]. It is likely that an increase in cholesterol content is due to the intensification of bile acid synthesis. In addition, an increase in the LDH activity in rat liver leads to an increase in concentration of pyruvate, that can be used for synthesis of cholesterol [18].

Total activity of AST in animals liver in the I and II experimental groups was higher by 21.4 and $19.7 \%$ than in the control group. The activity of the mitochondrial form of AST (mAST) was higher by 93.3 and $80.0 \%$ compared to control. Despite the fact that in the liver of rats of the III experimental group the activity of AST remains on the control level, the activity of its mitochondrial isozyme was higher by $83.3 \%$, and the cytoplas- 
mic one was lower by $20.6 \%$ than in the liver of animals of the control group. Thus, the total activity of AST in the liver of rats of all experimental groups was increased by one to the activity of mAST (Fig. 1).

\section{Table 1. Biochemical parameters in rat liver during long-term taurine treatment}

\section{Таблиця 1. Біохімічні показники печінки щурів за тривалого введення таурину}

\begin{tabular}{|c|c|c|c|c|}
\hline \multirow{2}{*}{ Parameter } & \multicolumn{4}{|c|}{ Animal group } \\
\hline & Control & I $(5 \mathrm{mg} / \mathrm{kg})$ & II $(10 \mathrm{mg} / \mathrm{kg})$ & III (20 mg/kg) \\
\hline LDH, UI/mg of protein & $2.73 \pm 0.33$ & $5.79 \pm 0.37^{* * *}$ & $4.53 \pm 0.36^{* * *}$ & $5.14 \pm 0.41^{* * *}$ \\
\hline $\begin{array}{l}\text { Cholesterol content, } \\
\mu \mathrm{mol} / \mathrm{mg} \text { of protein }\end{array}$ & $69.4 \pm 2.7$ & $69.9 \pm 4.0$ & $91.9 \pm 8.3^{*}$ & $68.1 \pm 6.7$ \\
\hline AST, $\mu$ catal $/ \mathrm{mg}$ of protein & $0.217 \pm 0.005$ & $0.239 \pm 0.004^{*}$ & $0.244 \pm 0.004^{* *}$ & $0.210 \pm 0.009$ \\
\hline $\mathrm{cAST}, \mu \mathrm{catal} / \mathrm{mg}$ of protein & $0.187 \pm 0.007$ & $0.181 \pm 0.002$ & $0.187 \pm 0.06$ & $0.155 \pm 0.006^{*}$ \\
\hline $\mathrm{mAST}, \mu \mathrm{catal} / \mathrm{mg}$ of protein & $0.030 \pm 0.001$ & $0.058 \pm 0.004^{* *}$ & $0.054 \pm 0.004^{\star *}$ & $0.055 \pm 0.003^{* *}$ \\
\hline ALT, $\mu$ catal/mg of protein & $0.229 \pm 0.008$ & $0.314 \pm 0.007^{* * *}$ & $0.293 \pm 0.016^{*}$ & $0.253 \pm 0.006$ \\
\hline $\mathrm{cALT}, \mu \mathrm{catal} / \mathrm{mg}$ of protein & $0.184 \pm 0.007$ & $0.234 \pm 0.007^{* *}$ & $0.229 \pm 0.016^{* *}$ & $0.193 \pm 0.005$ \\
\hline $\mathrm{mALT}, \mu \mathrm{catal} / \mathrm{mg}$ of protein & $0.045 \pm 0.003$ & $0.080 \pm 0.006^{* *}$ & $0.064 \pm 0.002^{* *}$ & $0.061 \pm 0.001^{*}$ \\
\hline
\end{tabular}

Comments: here and below * - statistically significant difference compared to values of the control group with $\mathrm{P}<0.05 ;{ }^{* *}$ - with $\mathrm{P}<0.01$; ${ }^{* *}$ - with $\mathrm{P}<0.001$

Примітки: тут і далі * - статистично вірогідна різниця щодо показників контрольної групи з $\mathrm{P}<0,05$; ** $-3 \mathrm{P}<0,01 ;$ *** $-3 \mathrm{P}<0,001$

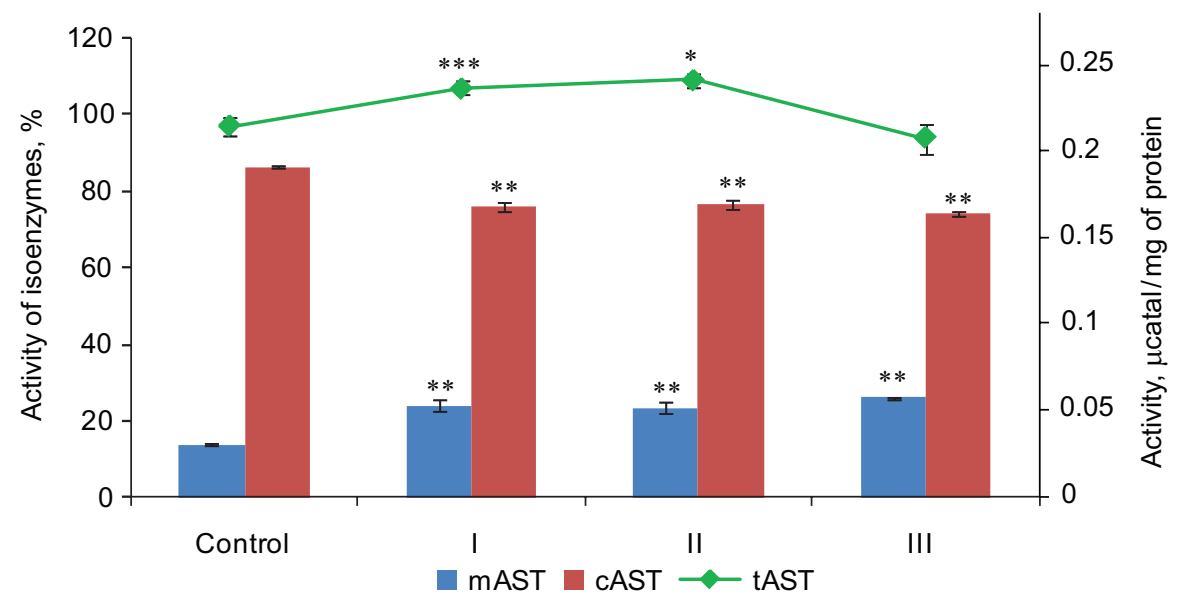

Fig. 1. The effect of long-term oral administration of taurine on percentage of mitochondrial (mAST) and cytoplasmic (CAST) isozymes activity of aspartate aminotransferase on the background of changes in the total activity of AST (tAST)

Рис. 1. Вплив тривалого перорального введення таурину на відсоткове співвідношення активностей ізозимів мітохондріальної (мАСТ) та цитоплазматичної (цАСТ) аспартатамінотрансфераз на тлі зміни загальної активності АСТ (зАСТ)

ISSN 1996-4536 (print) • ISSN 2311-0783 (on-line) • Біологічні Студії / Studia Biologica • 2018 • Том 12/№1 • С. 25-34 
Elevated mAST activity indicates an increase in the aspartate and $\alpha$-ketoglutarate synthesis. In its turn, $\alpha$-ketoglutarate can be included in the Krebs cycle or used as a co-substrate in the cytoplasmic oxygenase reactions [25].

The total ALT activity was increases by 37.1 and $28.0 \%$ in rat liver of I and II experimental groups, respectively. The activity of cytoplasmic isozyme was increased (cALT, by 27.2 and $24.5 \%$ ), and of the mitochondrial isozyme (mALT; by 77.8 and $42.2 \%$, respectively, Table 1). Although the activity of ALT was not increased in liver of animals of III experimental group, the activity of its mitochondrial isozyme was increased by $35.6 \%$. An increase of the total activity of ALT in the I and III study group was due to growth of mALT (Fig. 2). In II experimental group, the ratio between isozyme activity remained unchanged.

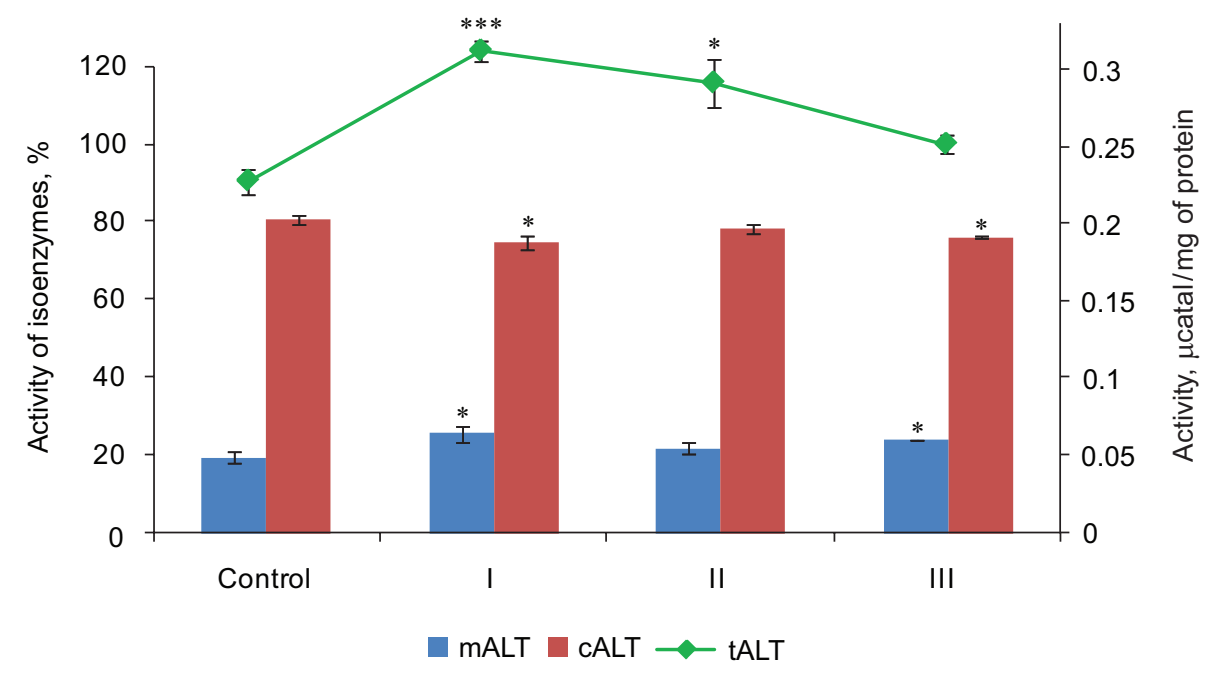

Fig. 2. Change in ratio between isozyme activity of mitochondrial (mALT) and cytoplasmic (cALT) alanine aminotransferase on the background of a change in total activity ALT (tALT) after a long-term per oral injection of taurine

Рис. 2. Зміна відсоткового співвідношення активностей ізозимів мітохондріальної (мАЛт) і цитоплазматичної (цАЛТ) аланінамінотрансфераз на тлі зміни загальної активності АЛТ (зАЛТ) за тривалого перорального введення таурину

An increase in mALT activity in animals of all experimental groups indicates an intensification of the production of pyruvate and glutamate [2]. Glutamate is used in mitochondria as a substrate for transamination and formation of aspartate [7]. Pyruvate is oxidized by the pyruvate dehydrogenase and is included into Krebs cycle, or into synthesis of cholesterol, or glucose in the hepatocyte cytoplasm [8]. The latter is less likely, since in animals of all experimental groups the concentration of glucose in blood was lower than in control animals [20]. Increased concentration of pyruvate can intensify the rate of Krebs cycle reactions and increase the transport of electrons in the respiratory chain. This caused intensification of peroxide lipid oxidation and increased activity of antioxidant enzymes [18].

It was shown that oral treatment with taurine for 28 days in doses of 40 and $100 \mathrm{mg} /$ $\mathrm{kg}$ increased the activity of SOD in rats liver [24]. An injection of taurine in esophagus in

ISSN 1996-4536 (print) • ISSN 2311-0783 (on-line) • Біологічні Студії / Studia Biologica • 2018 • Том 12/№1 • С. 25-34 
10 and $20 \mathrm{mg} / \mathrm{kg}$ doses during the same period increased the activity of SOD in the submithohondrial fraction of rat liver by 49.8 and $36.5 \%$ (Table 2). The activity of GPO and KAT in the submithohondrial fraction of liver remained at the control level in animals of all experimental groups. Nevertheless, the GPO/ CAT ratio decreased equally - by $10.6 \%$ - in rats in the I and II experimental groups, that may indicate an increase in production of the hydrogen peroxide. The growth of SOD activity in the submithohondrial liver fraction of II and III experimental groups led to an increase by 40 and $46.7 \%$ of SOD / KAT ratio and by 55.9 and $48.4 \%$ of the SOD / GPO ratio. That might may indicate an increase in the production of superoxide anion radical. Despite an increase in SOD activity, the content of TBA-active products increased 2.8 and 3.0 times in rats of the II and III experimental groups. A 2-3 times decrease of AOD/TBA coefficient in rats of these groups indicates an inability to utilize formed free oxygen radicals. In the submitochondrial fraction of rat liver of I experimental group, the content of TBA-active products was $21.1 \%$ lower than in the control. This may suggest that in low doses taurine inhibits lipid peroxidation in rat liver, and in high doses - it intensifies it. The latter might by a result of intensification of oxidative metabolism that leads to the activation of superoxide dismutase [18].

In the mitochondrial fraction of all experimental group rats, the activity of SOD and CAT remained at the control level. In animals of I experimental group, GPO activity was $20.4 \%$ higher than in control. At the same time, the content of TBA-active products increases by 2-2.5 times and AOP/TBC ratio reduced by 75.4 and $37.6 \%$ in liver of the mitochondrial fraction of animals of the II and III experimental groups. This indicates an increase in the processes of lipid peroxide oxidation, releasing oxygen free radicals, and, possibly, the intensification of transport of electrons through the respiratory chain. In liver mitochondrial fraction of III experimental group rats, the HPA / CAT ratio reduced by $25.0 \%$ that may indicate an increased production of $\mathrm{H}_{2} \mathrm{O}_{2}$.

Consequently, a long-term oral treatment of taurine at $5-20 \mathrm{mg} / \mathrm{kg}$ doses led to increased the activity of LDH in liver. This may indicate an increase in the production of lactate by other tissues, since liver is a central organ where lactate is transformed into pyruvate [13]. In turn, pyruvate which is produced by LDH in liver, can be used for synthesis of cholesterol or be included in Krebs cycle, thus, increasing concentration of $\mathrm{NADH}^{+}$and $\mathrm{FADH}_{2}$ [18] (Fig. 3).

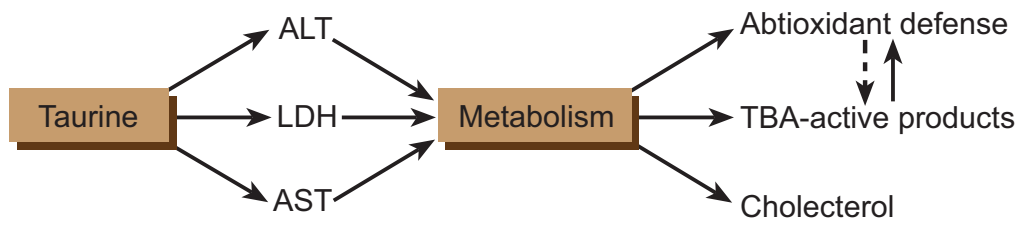

Fig. 3. Possible effect of long-term taurine treatment on metabolism of rat liver (the inseparable line shows the intensification, and the dotted line - inhibition)

Рис. 3. Можливий вплив тривалого перорального введення таурину на метаболізм печінки щурів (нерозривною лінією показано інтенсифікацію, а пунктиром - інгібування)

An increase in mAST activity may also intensify metabolism as $\alpha$-ketoglutarate is synthesized. It may be included in the Krebs cycle or transported from the mitochondria into the cytoplasm and used for oxygenase reactions [3]. The latter partly explains the

ISSN 1996-4536 (print) • ISSN 2311-0783 (on-line) • Біологічні Студії / Studia Biologica • 2018 • Том 12/№1 • С. 25-34 
Table 2. Influence of long-term tauirne treatment on antioxidant defense in rat liver Таблиця 2. Вплив тривалого введення таурину на антиоксидантний захист печінки щурів

\begin{tabular}{|c|c|c|c|c|}
\hline \multirow{2}{*}{ Parameter } & \multicolumn{4}{|c|}{ Animal group } \\
\hline & Control & I (5 mg/kg) & II (10 mg/kg) & III (20 mg/kg) \\
\hline \multicolumn{5}{|c|}{ Submitochondrial fraction } \\
\hline SOD, UI/mg of protein & $2.19 \pm 0.26$ & $2.36 \pm 0.17$ & $3.28 \pm 0.10^{* *}$ & $2.99 \pm 0.10^{*}$ \\
\hline $\begin{array}{l}\mathrm{GPO}, \mu \mathrm{mol} \mathrm{GSH} / \mathrm{min} \times \mathrm{mg} \\
\text { of protein }\end{array}$ & $0.230 \pm 0.014$ & $0.214 \pm 0.015$ & $0.218 \pm 0.006$ & $0.214 \pm 0.015$ \\
\hline $\begin{array}{l}\mathrm{CAT}, \mu \mathrm{mol} \mathrm{H}_{2} \mathrm{O}_{2} / \mathrm{min} \times \mathrm{mg} \\
\text { of protein }\end{array}$ & $14.94 \pm 0.76$ & $15.75 \pm 0.52$ & $16.02 \pm 0.11$ & $13.94 \pm 0.70$ \\
\hline $\begin{array}{l}\text { TBA-active products, } \\
\mathrm{mmol} / \mathrm{mg} \text { of protein }\end{array}$ & $0.147 \pm 0.007$ & $0.116 \pm 0.007^{*}$ & $0.593 \pm 0.032^{*}$ & $0.568 \pm 0.040^{*}$ \\
\hline SOD/CAT, UI & $0.15 \pm 0.02$ & $0.15 \pm 0.01$ & $0.21 \pm 0.01^{*}$ & $0.22 \pm 0.01^{*}$ \\
\hline SOD/GPO, UI & $9.52 \pm 1.11$ & $10.85 \pm 0.03$ & $14.84 \pm 0.63^{* *}$ & $14.13 \pm 1.26^{*}$ \\
\hline GPO/CAT, UI & $15.5 \pm 0.2$ & $13.8 \pm 0.2^{*}$ & $13.8 \pm 0.2^{*}$ & $15.65 \pm 1.0$ \\
\hline AOD/TBA, UI & $53.33 \pm 10.13$ & $69.81 \pm 3.60$ & $19.77 \pm 1.24^{*}$ & $15.81 \pm 2.43^{*}$ \\
\hline \multicolumn{5}{|c|}{ Mitochondrial fraction } \\
\hline SOD, Ul/mg of protein & $0.39 \pm 0.03$ & $0.45 \pm 0.03$ & $0.45 \pm 0.03$ & $0.39 \pm 0.03$ \\
\hline $\begin{array}{l}\mathrm{GPO}, \mu \mathrm{mol} \mathrm{GSH} / \mathrm{min} \times \mathrm{mg} \\
\text { of protein }\end{array}$ & $0.054 \pm 0.002$ & $0.065 \pm 0.004^{*}$ & $0.056 \pm 0.003$ & $0.060 \pm 0.001$ \\
\hline $\begin{array}{l}\mathrm{CAT}, \mu \mathrm{mol} \mathrm{H}_{2} \mathrm{O}_{2} / \mathrm{min} \times \mathrm{mg} \\
\text { of protein }\end{array}$ & $2.21 \pm 0.08$ & $2.67 \pm 0.21$ & $2.48 \pm 0.11$ & $2.29 \pm 0.06$ \\
\hline $\begin{array}{l}\text { TBA-active products, } \\
\mathrm{mmol} / \mathrm{mg} \text { of protein }\end{array}$ & $0.047 \pm 0.001$ & $0.045 \pm 0.004$ & $0.112 \pm 0.008^{\star *}$ & $0.093 \pm 0.005^{\star *}$ \\
\hline SOD/CAT, UI & $0.18 \pm 0.01$ & $0.17 \pm 0.01$ & $0.18 \pm 0.01$ & $0.13 \pm 0.01$ \\
\hline SOD/GPO, UI & $7.11 \pm 0.35$ & $6.80 \pm 0.24$ & $8.06 \pm 0.24$ & $6.58 \pm 0.61$ \\
\hline GPO/CAT, UI & $0.025 \pm 0.001$ & $0.025 \pm 0.001$ & $0.023 \pm 0.001$ & $0.020 \pm 0.001^{* *}$ \\
\hline AOD/TBA, UI & $1.00 \pm 0.12$ & $1.76 \pm 0.23^{*}$ & $0.57 \pm 0.05^{*}$ & $0.727 \pm 0.03^{*}$ \\
\hline
\end{tabular}

increase in the content of TBA-active products in the submithohondrial fraction, as superoxide anion is released during the oxidation of the substrates. In addition, the elevation of $\alpha$-ketoglutarate synthesis may result in the increase of mALT activity [2].

In conclusion, long-term per oral taurine treatment in dose $5 \mathrm{mg} / \mathrm{kg}$ for 28 days resulted in transaminase (AST and ALT) and LDH activity rise. That might led to inten- 
sification of liver metabolism. After treatment with taurine solution in doses 10 and $20 \mathrm{mg} / \mathrm{kg}$, the activity of transaminases and LDH were higher than in control, and the content of TBA-products was increased.

1. Dubinina E.E. Salnicova L.Ya., Yefimova L.F. Activity and izozyme spectrum of superoxide dismutase of erythrocytes. Lab. Work, 1983; 10: 30-33. (In Russian).

2. Evans G.O. Animal clinical chemistry. Taylor\&Francis, 2005. 222 p.

3. Hangasky J.A., Taabazuing C.Y., Martin C.B. et al. The facial triad in the a-ketoglutarate dependent oxygenase $\mathrm{FIH}$ : A role for sterics in linking substrate binding to $\mathrm{O}_{2}$ activation. Journal of Inorganic Biochemistry, 2017; 166: 26-33.

4. Hansen S. H., Birkedal H., Wibrand F. et al. Taurine and regulation of mitochondrial metabolism. Adv. Exp. Med. Biol, 2015; 803: 397-405.

5. Holod V.M., Kurdeko A.P. Clinical biochemistry: tutorial in 2 tomes. Vitebsk, 2005. V. 2. P. 20. (In Russian).

6. Kamishnikov V.S. Handbook of clinical and biochemical studies and laboratory diagnosis. Moscow: MEDpress-inform, 2004. 459 p. (In Russian).

7. Karim F., Rahman R., Shermin S. et al. Correlation between aminotransferase ratio (AST/ ALT) and other biochemical parameters in chronic liver disease of viral origin. Delta Med. Col. J, 2015; 3: 13-17.

8. Knudsen A.R., Andersen K.J., Hamilton-Dutoit S. et al. Correlation between liver cell necrosis and circulating alanine aminotransferase after ischaemia/reperfusion injuries in the rat liver. International Journal of Experimental Pathology, 2016; 97(2): 133-138.

9. Kondrashova M. N. Transaminase cycle of substrate oxidation in cell, as an adaptation mechanism to hypoxia. Pharm. Corr. Hypox. Stat, 1989; 1: 51-70. (In Russian).

10. Korabieynikova S.N. Modification of the definition of lipid peroxidation method reaction with TBA. Lab. Work, 1989; 7: 8-10. (In Russian).

11. Korolyuk M.A., Ivanova L.I., Mayorova I.G. et al. The method for determining the activity of catalase. Lab. Work, 1983; 10: 16-18. (In Russian).

12. Lambert I.H., Kristensen D.M., Holm J.B. et al. Physiological role of taurine - from organism to organelle. Acta Physiol, 2015; 203: 191-202.

13. Lossos I. S., Intrator O., Berkman N. et al. Lactate dehydrogenase isoenzyme analysis for the diagnosis of pleural effusion in haemato-oncological patients. Respir. Med, 1999; 93(5): 338-341.

14. Lowry O.H., Rosebrough N.J., Fair A.L. et al. Protein measurement with Folin phenol reagent. J. Biol. Chem, 1951; 193: 265-275.

15. McDonald J.H. Handbook of Biological Statistics. Baltimore: Sparky House Publishing, 2014. 305 p.

16. Miyazaki T., Matsuzaki Y. Taurine and liver diseases: a focus on the heterogeneous protective properties of taurine. Amino Acids, 2014; 46(1): 101-110.

17. Moin V.M. A simple and specific method for determining the activity of glutathione peroxidase in erythrocytes. Lab. Work, 1986; 12: 724-727. (In Russian)

18. Nelson D.L., Cox M.M. Lehninger principles of biochemistry. Fifth edition. New York: W.H. Freeman and Company, 2011. $1282 \mathrm{p}$.

19. Orct T., Jurasović J., Micek V. et al. Macro- and microelements in the rat liver, kidneys, and brain tissues; sex differences and effect of blood removal by perfusion in vivo. Journal of Trace Elements in Medicine and Biology, 2017; 40: 104-111.

20. Ostapiv R., Skyba Chr., Manko V. Effect of long-term peroral taurine injection on blood indexes of rats. Visnyk of the Lviv University. Series Biology, 2017; 75: 146-150.

21. Ostapiv R.D., Manko V.V. Mitochondria respiration and oxidative phosphorilation of rat tissues at taurine per oral injection. The Ukrainian Physiological Journal, 2015; 61: 103-112.

ISSN 1996-4536 (print) • ISSN 2311-0783 (on-line) • Біологічні Студії / Studia Biologica • 2018 • Том 12/№1 • С. 25-34 
22. Ostapiv R.D., Manko V.V. Activity and isozyme content of lactate dehydrogenase under longterm oral taurine administration to rats. The Ukrainian Biochemical Journal, 2015; 87(4): 54-62.

23. Ostapiv R.D., Kisciv O., Manko V.V. Effect of taurine oral long-term administration on physiological parameters of rats. Visnyk of the Lviv University. Series Biology, 2015; 69: 247-255.

24. Ostapiv R.D., Manko V.V. Antioxidant defense of rat organism at long-term per oral taurine injection. Studia Biologica, 2016, 9: 59-70.

25. Ribeiro R. A., Bonfleur M. L., Amaral A. G. et al. Taurine supplementation enhances nutrientinduced insulin secretion in pancreatic mice islets. Diabetes Metab. Res. Rev, 2009; 25(4): 370-379.

26. Rodella P., Takase L. F., dos Santos J. L. The Effect of Taurine on Hepatic Disorders. Curr. Updates Hepatol. Gastroenterol, 2017; 1: 2-13.

27. Xu B., Ganesan K., Jayachandran M. A critical review on hepatoprotective effects of bioactive food components. Critical Reviews in Food Science and Nutrition, 2017; 1-65.

\title{
АКТИВНІСТЬ ЕНЗИМІВ ПЕЧІНКИ СТАТЕВОЗРІЛИХ ЩУРІВ ЗА ТРИВАЛОГО ПЕРОРАЛЬНОГО ВВЕДЕННЯ ТАУРИНУ
}

\author{
P. Ocmanis ${ }^{1,2}$, X. Ocmanis ${ }^{1}$, В. Манько \\ 1 Львівський національний університет імені Івана Франка \\ вул. Грушевського, 4, Львів 79005, Україна \\ ${ }^{2}$ ДНДКІ ветеринарних препаратів та кормових добавок \\ вул. Донецька, 11, Львів 79019, Україна \\ e-mail: romostapiv@gmail.com
}

Таурин - сірковмісна похідна метіоніну і цистеїну, що відіграє ключову роль у метаболізмі глюкози та ліпідів. Відомо, що таурин регулює активність антиоксидантної системи, мембранний потенціал мітохондрій і гліколіз. Таким чином, таурин відіграє ключову роль у метаболізмі клітин організму ссавців. Метою роботи було дослідити вплив тривалого перорального введення таурину дозами 5, 10 та 20 мг/кг на стан антиоксидантного захисту, вміст холестерину, активність ензимів трансамінування та лактатдегідрогенази у печінці щурів. Для досягнення мети статевозрілих самців щурів лінії Wistar (масою 140-160 г та віком 4 місяці) розділяли на чотири групи - контрольну, яким протягом 28 діб щоденно вводили у стравохід питну воду (контроль), та три дослідні, яким вводили таурин у дозах: І дослідна 5 мг/кг, II дослідна - 10 мг/кг і III дослідна групи - 20 мг/кг маси тіла. У печінці щурів визначали: масу, активність ензимів антиоксидантного захисту, трансамінування, лактатдегідрогенази, вміст холестерину і ТБК-активних продуктів.

У результаті досліджень виявлено, що тривале пероральне введення таурину приводить до зниження маси печінки на 27,5 \% у щурів II дослідної групи. Активність лактатдегідрогенази зростає у два рази та мітохондріальних ензимів трансамінування - на 40-90 \%, у тварин усіх дослідних груп. Загальна активність аспартат і аланін амінотрансфераз зростає на 20-37 \% у всіх дослідних групах. У тварин II дослідної групи на 32,4 \% зростає вміст холестерину. Це може вказувати на інтенсифікацію метаболізму печінки. Водночас у II та III дослідних групах зростає у більш як удвічі вміст ТБК-активних продуктів у субмітохондріальній і мітохондріальній фракції. Активність супероксиддисмутази у субмітохондріальній фракції -

ISSN 1996-4536 (print) • ISSN 2311-0783 (on-line) • Біологічні Студії / Studia Biologica • 2018 • Том 12/№1 • С. 25-34 
зростає на 49,8 і 36,5 \%. Активація супероксиддисмутази та зростання вмісту ТБКактивних продуктів може вказувати на зростання продукції вільних радикалів оксигену і нездатність антиоксидантної системи захисту утилізувати їх. Наші результати можуть свідчити про негативний вплив доз таурину, вищих, ніж 5 мг/кг, оскільки порушується баланс між антиоксидантним захистом і процесами пероксидного окиснення ліпідів.

Ключові слова: щури, печінка, антиоксидантний захист, таурин, лактатдегідрогеназа, ензими трансамінування

Одержано: 07.02.2018 